\author{
Andrea SCHMIDT \\ University of Pecs, Hungary \\ schmidt.andrea@pte.hu
}

\title{
FROM INTERMARIUM TO THE THREE SEAS \\ INITIATIVE - REGIONAL INTEGRATIONS \\ IN CENTRAL AND EASTERN EUROPE \\ AND THE HUNGARIAN FOREIGN POLICY ${ }^{1}$
}

ABSTRACT The aim of the paper is to examine the harmony between the Polish and the Hungarian foreign policy from the early $20^{\text {th }}$ century to the recent decades. Due to their special geographical position both states experienced threats and challenges in the examined period, however their approach to the above was different. Poland was focusing on the problem of the rebirth of the divided state and the uncertainty regarding its borders while Hungary had to struggle with the peaceful revision of the lost territories. Being located between two ambitious great powers Poland and Hungary had to find balance between German and Russian (Soviet) aspirations that influenced the foreign policy of both states. This paper treats Poland as a reference point and examines the Hungarian struggles from this approach. The paper also gives an outline definition of the meaning of borders and their importance in Central and Eastern European region.

Key words: foreign policy, borders, regional integration

\section{The area between the Adriatic, the Baltic and the Black Sea is the lifeblood of Europe. ${ }^{2}$}

\footnotetext{
Research for this paper was supported by the following grant: EFOP-3.6.3-VEKOP-16-2017-00007 Young researchers from talented students - Fostering scientific careers in higher education.

2 These were the opening words of the host, Croatian President Grabar-Kitarović, at the forum, held in Dubrovnik on Thursday, August 25, on the cost of the Adriatic Sea. The following presidents were present: the presidents of Croatia, Hungary, Poland, Bulgaria, Lithuania and Slovenia, as well as ministers and deputy ministers of Austria, Czechia, Estonia, Latvia, Romania, and Slovakia. "The Three Seas Initiative: Central and Eastern Europe Takes Charge of its Own Destiny”, Visegrád Post, 28 August 2016, at <https://visegradpost.com/en/2016/08/28/the-three-seas-initiative-central-and-easterneurope-takes-charge-of-its-own-destiny $>$.
} 
The aim of this article is to examine the Polish initiatives towards the Central European cooperation from the early $20^{\text {th }}$ century and their impact on the Hungarian foreign policy with a special emphasis on the problems of borders and the challenge of regional cooperation. Thanks to their special geographical position Poland and Hungary had a historical experience based on the changing borders and its impact on national identity. While the First World War and the peace treaties re-drew the political map of Central and Eastern Europe old empires collapsed and disappeared from this map while new successor states were born with new borders that sometimes became unstable. Hungary had to get used to the reduced size of its territory and the loss of $60 \%$ of the population ${ }^{3}$ and the change in the share of Hungarians and the ethnic minorities. From a multiethnic state, Hungary became a homogeneous nation-state. According to the census of 1910, the share of Hungarians in the total population was roughly 54\%, as the consequence of territorial loss by 1920 their share reached $90 \%$. The critics of the Trianon peace treaty claim that although different ethnic minority groups located in Hungary were fighting for their independent nation states finally the new Hungarian state with reduced territory remained the only pure nation-state while the successor states got hundred thousands of Hungarians with unsolved national self-determination and minority rights protection. This controversial situation poisoned the relation between Hungary and the successor states that resulted in mutual distrust. Their hostile behaviour towards each other hampered any kind of cooperation that would have been necessary being locked between the two great powers, Soviet Union and Germany.

While Hungary struggled with territorial loss, Poland had to focus on the problems of territorial integrity. Poland was also acquainted with the challenges of sovereignty and its controversial initiatives regarding the borders and having new, mostly unfriendly neighbours. However, having experienced being subordinated to dominating empires, Poland's foreign policy focused on finding potential partners to fight against the pressure coming from the East and the West, while Hungary's approach focused on the problem of the peaceful territorial revision, i.e. to get back as much territory as it was possible based on the principles of national self-determination. These very specific, rather controversial aims of the two states influenced their relations in the $20^{\text {th }}$ century.

\section{BORDERS IN CENTRAL AND EASTERN EUROPE}

Border as a phenomenon got its importance with the birth of the nation states in the $19^{\text {th }}$ century and kept it through several centuries. However, the contradictory yet simultaneous functions of walls, borders, and boundaries - to divide and connect, to exclude and include, to shield and constraint - is fundamental to all cultures regard-

\footnotetext{
“Magyarországon a XX. században - Magyarország népessége”, Magyar Elektronikus Könyvtá, at <http://mek.oszk.hu/02100/02185/html/171.html . The data are taken from the census from 1910 and 1920 . While in 1910 altogether more than 18 million people lived in Hungary (not including the territory of Croatia, which had been integrated into the Hungarian Kingdom since the $12^{\text {th }}$ century), by 1920 within the new borders less than 8 million Hungarian remained.
} 
less time and space. ${ }^{4}$ After the First World War, with the collapse of the great empires in Central and Eastern Europe, state borders strengthened their separating role. While mutable borders are signs of life, closed borders signify ethnic or political division and often literally cause death. Moreover, even in times of peace borders have often been perceived as dead zones, as peripheral regions separated from the national 'core' - its wealth, its power, and the independence of its capital city. When the wall, border, or boundary is closed or remote, these zones usually function as conquered, relatively empty second-class areas. ${ }^{5}$

Walls, borders, and boundaries also are traced far beyond and deeply within the obvious edges of nation-states. They are usually far from fixed static entities: barrier sites and barrier processes do not solely offer tales of domination and separation. ${ }^{6}$ They are much more than just histories of survellier et punier (control and punish); rather they offer narratives of Foucauldian 'anti-discipline' as well as possibilities of identity formation. They are also dynamic spaces of inhabitation that exceed those of the nation-state; they offer possibilities of survival and adaptation and the hope of self-transformation. They can also be expressed as activist markers that encourage people to assume political responsibility for a pursuit of a decent life extending beyond the borders of individual countries. ${ }^{7}$ Henri Lefebvre, the famous French philosopher and sociologist in his work The Production of Space analysed how modern spaces are the representation of space, the spaces of representation, and spatial practice. According to his standpoint the space of representation is directly lived through in associated images and symbols, and hence [it is] the space of 'inhabitants' and 'users.'

The improvement of national identity in the age of modernization took place in parallel with the development of regional identity. The $19^{\text {th }}$ century was the age of birth of nation-states, however, regarding the position of the nations in Central and Eastern Europe the monarchies and empires under dynastic order were much more widespread. Thus that determined the fate of the nations, living under foreign supremacy, however, at a certain point, it also helped them to strengthen the attempts to autonomous status or later, the achievement of independence. By the $19^{\text {th }}$ century, most of the nations living in Central and Eastern Europe faced the problem that Hroch calls 'nation-building

M. Silberman, K.E. Till, J. Ward (eds.), Walls, Borders, Boundaries. Spatial and Cultural Practices in Europe, New York-Oxford 2012, pp. XV-XVI.

5 The Polish Central Industrial Zone is a typical example of this issue. In the inter-war period, a Central Industrial Zone was built up in the central region of Poland. As a consequence of the territorial changes based on the agreement in Potsdam in 1945 Poland became pushed towards the West and the Central Industrial Zone remained in the Eastern bordering region of Poland. After the collapse of Socialist economic cooperation, it became one of the depression zones of Poland and it required tremendous sums to invest in order to eliminate the gap between Eastern Poland and the more developed regions.

$6 \quad$ M. Silberman, K.E. Till, J. Ward (eds.), Walls, Borders, Boundaries..., p. 6.

7 Ibid.

8 M. Mariani, P. Barron (eds.), Terrain Vague. Interstices at the Edge of the Pale, London 2013, p. 127. 
strategy" that usually began with the realization of national self-consciousness referring the cultural, linguistic, cultural, social and historical attributes of the nation-to-be. It is similar to the phenomenon that appears in Herder's vision, too, as he distinguished nations living within more-or-less defined borders of nation-state and nations that found themselves in the lack of such elements.

There are also other additional elements necessary for the development of a nation like its own interests and values that should enjoy the priority over all other interests and values and the problem of independence. As Breully remarks, ${ }^{10}$ the nation must be as independent as possible that usually requires at least the attainment of political sovereignty.

The examination of the roles of the borders is a complicated problem. The first question is the way in which we make a definition of the role and the appearance of borders. There are physical aspects, such as the process of designation of borders, the changing of borders, or even their disappearance. The second problem is the examination of the spatial changes of borders, the definition of the question what kind of decision could affect how they actually change, what kind of conflicts could arise after the new positions of borders.

Table 1. Classification of the borders

\begin{tabular}{|c|c|}
\hline Component & Characteristic element \\
\hline Geographical & Spatial unity \\
\hline Political & Common interests, common problems \\
\hline Economic & Complexity of national economy, impossibility of autarchy \\
\hline Historical & $\begin{array}{c}\text { Cultural and social homogeneity, similar level of development, similar political } \\
\text { culture }\end{array}$ \\
\hline
\end{tabular}

Edited by the author, based on L. Bialasewicz, "Reordering Europe’s Eastern Frontier. Galician Identities and Political Cartographies on the Polish-Ukrainian Border”, Manuscript, 1999.

Establishing borders was always a great challenge in the Central and Eastern European region. As for many decades, three great powers shared their influential zones over this territory it is rather difficult to speak about a common decision based on the interest of the local people. Historical and national claims expressed the recalling of violent events that often ended with brutal intervention of the ruling power against the insurgents, not to oppose the imperial interest by causing instability. The birth of borders, however, is motivated in the following ways: borders can be created from above by the state that naturally does not necessarily reflect the interest of the local population. Borders can be drawn from outside, too. Usually that happens after the end of wars and in the majority of examples from past peace treaties, usually only the winners have the

9 M. Hroch, "From National Movement to the Fully Formed Nation; The Nation Building Process in Europe", in G. Balakrishnan (ed.), Mapping the Nation, London 1996, pp. 79-81. 
chance to gain their ambition Several examples prove that such decisions seemed to serve only as temporary solutions and in many cases, they were the roots of further conflicts and lack of cooperation among the hurt partners. Borders can also be established from the inside as a result of national claims, however, that is rather a risky attempt from the ruling nation. Giving autonomous status or even support to the attempts towards independence can have dual consequences. Getting rid of the insurgent nations and political actors can increase the internal stability of the remaining state however it can serve as an example for the rest of the other nations in their fights for independence. It was a typical issue in Central and Eastern Europe that the ethnic and the political borders did not coincide in the past two centuries and instead of homogeneous structures, multi-ethnic states were in dominant position.

There is another classification of borders that focuses on the problem whether borders are natural or artificial. As in Europe, the majority of the borders are a result of international agreement and natural borders appears only in few cases. ${ }^{11}$ Artificial borders were dominant as a result of international decisions forced by great powers. The characteristic elements of these borders was that they usually did not reflect the will of the beneficent.

The transition period between 1918 and 1921 was the proof that national demands and international political decisions were not always in accordance with each other. Both new Polish and Hungarian states within the new political borders remained a conflict zone in the interwar period. The Eastern borderland of Poland, a flat plain territory located between European and Asian civilization dividing Poland from the West and Russia from the East and was a potential battlefield and marching zone of different armies. By the $18^{\text {th }}$ century, the names of the geographic elements still proved the presence of different nations, and various dialects became widespread. ${ }^{12}$ This Eastern periphery became a melting pot of several ethnic groups and religions, which lived among peaceful conditions despite the fact that from time to time different attacks reached the region from different directions. The $19^{\text {th }}$ century, however, stopped the peaceful coexistence of different groups as nationalist ambitions determined the future of the local population. Final decisions about the borders were made by great powers

11 Natural borders are usually chains of mountains or seas that can divide different territories from each other. In the historical past, the Carpathian mountains served as natural borders in Central and Eastern Europe. They had the role of defense zones, too. Due to the political events and the decision of the great powers after the First World War, these mountains lost their original defense functions and became divided among the successor states. In present-day Europe two major natural borders are remarkable; the Alps as the natural borders of Italy and the Pyrenees as the natural boundary between France and Spain. Speaking about the Central and Eastern European region the actual landscape reflects the consequences of several border changes that resulted in a transitional zone between Poland, Ukraine, Belorussia, Moldova and Russia and originated several conflicts, too, that are still recognizable. F. Davis, “Europe's Natural Borders", Banging on about the Smoking Ban, 23 May 2016, at < https://cfrankdavis. wordpress.com/2016/05/23/europes-natural-borders/>.

12 A. Appelbaum, Kelet és Nyugat között - Európa határvidékén, Budapest 2016, pp. 16-17. 
based on their interest sometimes neglecting the claims of local ethnic groups. ${ }^{13}$ The new borders caused disappointment among winners and losers and hampered the cooperation among the new states in the next decades. As Churchill remarked, when the war of giants is over the wars of pygmies will begin. ${ }^{14}$ The historical events rewrote the borders of Poland from the late $18^{\text {th }}$ century until the decision in Potsdam in 1945. As this region became artificially divided based on the pressure of the Soviet politicians we can hardly speak about a homogeneous entity. The region was a victim of several recent geopolitical breakthroughs including those in 1914-21, 1939-45 and 2004-7. ${ }^{15}$

During the age of Cold War the borders that divided Europe also divided the world. They created the geopolitical division between East and West. The Iron Curtain both divided Europe, and because the division was exported to other parts of the world, also worked as a global border. The revolutions of 1989 brought, among other things, a profound reordering of the spatial imaginary of Europe. The collapse of the Berlin Wall and the collapse of the Soviet bloc rendered necessary new geographical stories, new spatial representation to capture and codify the cartographic chaos of the ex-Eastern European space. Although the cold war was over, the border did not disappear at once, however, especially from the second half of 1980s new discussions began about the structure of Europe.

The late 1980s became the age for debates about the division of the Central and Eastern European region and with this discussion, new questions and problems appeared. With the political transformation and the collapse of the Soviet Union, the history appeared as a crucial factor in the reorganization of the spatial structure of the region. The revolutions in 1989 brought, among other things, a profound reordering of the spatial imaginary of Europe. The new democracies of Poland, Hungary, and Czechoslovakia set out early in the decade to pursue Central-European co-operation, symbolized by their forming of the Visegrad Group. New ways of regional integration were to be set up as a natural consequence of historical heritage.

\section{TERRITORIAL CHANGES AFTER THE FIRST WORLD WAR}

After the First World War Poland and Hungary found themselves in a controversial situation. While Hungary had to struggle with the least hope for preserving its territorial integrity, Poland had a great chance to re-establish the frames of a new state. Paradoxically, until the very last moment at the peace conference the members of the Hungarian delegation were convinced that even if the negotiating powers interfered in the territorial integrity of the historical Hungary, only slight changes would be proposed by

13 During the five years of Russian and Polish War, at least 11 different armies were fighting for the future Ukraine and the last battle in 1920 caused the death of more than 20,000 cavalries. Ibid., p. 18.

14 "Winston Churchill Quotes", QuoteAuthor, at <http://www.quoteauthors.com/winston-churchillquotes/>.

15 T. Zarycki, Ideology of Eastness in Central and Eastern Europe, London-New York 2014, p. 136. 
the winners based on the principles of drawing borders according to the ethnic boundaries. The decisions of Trianon in 1920 resulted in the greatest loss for Hungary both as regards the territory, population and in infrastructure. The consequences of the territorial loss affected the restructuring of the share of different nations and the position of those ethnic Hungarians who remained outside the new borders of Hungary. By expressing the feelings about the loss and worrying about the fate of the Hungarians living in the successor states the foreign policy of the interwar Hungary focused on the revision of the borders and searching potential influential supporters from Europe. The new territorial frames and the birth of the succession states partly in the ruins of the collapsed Habsburg Empire including historical Hungary resulted in unsolvable conflicts between them that hampered the cooperation among them as they treated each other enemies. Hungary hence grabbed every opportunity to point to the injustice of the peace treaty.

Figure 1. The Treaty of Trianon

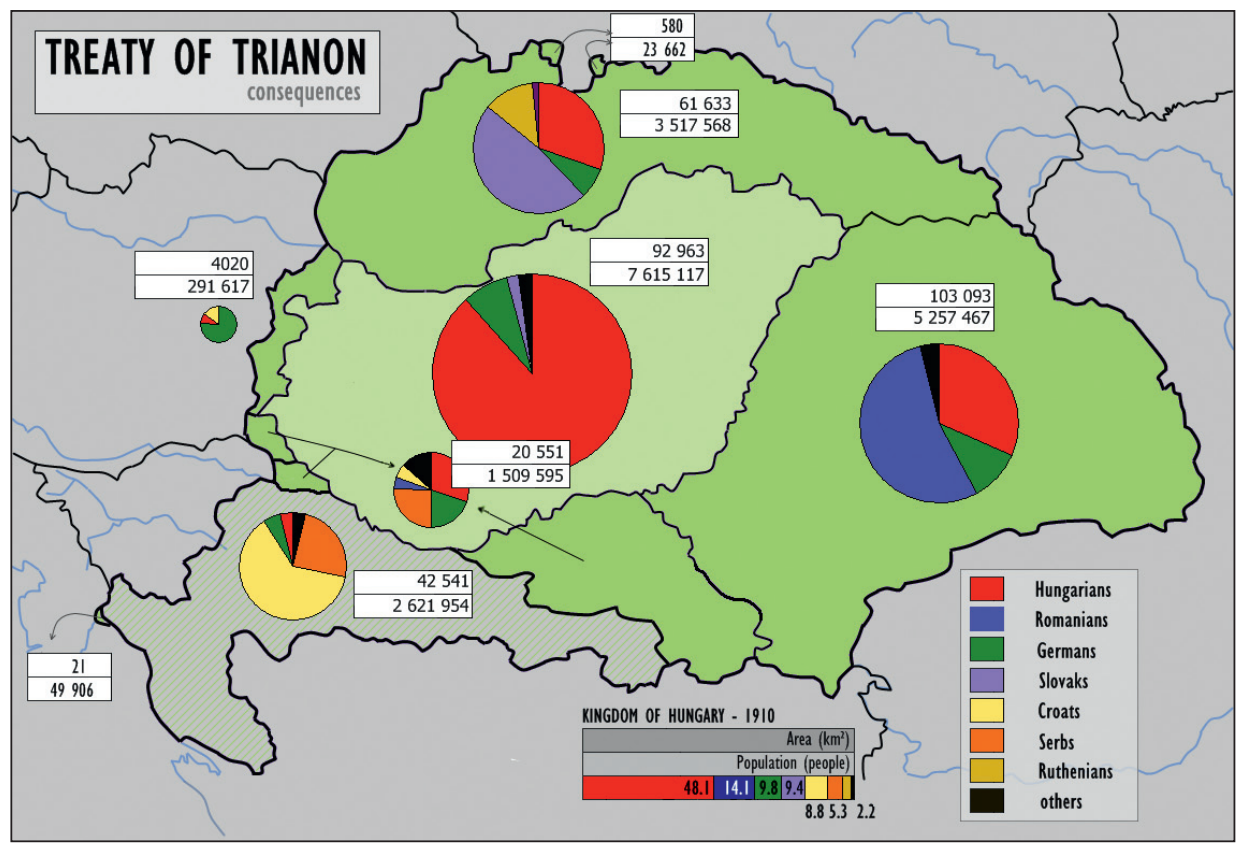

Source: The terms and effects of the Treaty of Trianon with Hungary, https://www.mrallsophistory.com/ revision/the-terms-and-effects-of-the-treaty-of-trianon-with-hungary.html.

The First World War and the hope of the restoration of independent Poland also raised the questions regarding borders and territorial integrity. Two opposite standpoints were composed. The Realistic standpoint was popular among the followers of the ideology the National Democrats. This vision meant among others the claim of unification of all Polish territories and building up correct relations with the Russians. 
Its ideological basis laid on nationalism and social Darwinism. According to their view, Poland was the symbol of a nation of Christianity. Although it emphasized Poland as the Saviour of Europe, this standpoint was even criticized by the church. Based on this standpoint, Poles were threatened by the surrounding nations and they should remain in one block. ${ }^{16}$ This view focused on a homogeneous Polish state.

However, the so-called 'Prometheanism' appeared in Piłsudski's program. According to this view Poland's strength and importance among the constituent parts of the Russian state embolden us to set ourselves the political goal of breaking up the Russian state into its main constituents and emancipating the countries that have been forcibly incorporated into that empire. We regard this not only as the fulfilment of our country's cultural strivings for independent existence but also as a guarantee of that existence since a Russia divested of her conquests will be sufficiently weakened that she will cease to be a formidable and dangerous neighbour. ${ }^{17}$ In his program, he emphasized that the pledge of independence of Poland is strongly connected with the situation of Ukraine, Lithuania, Belarus, however, Poland's aim is to regain the borders of the old Rzeczpospolita. In his further political program, he managed to create a synthesis and understanding the historical processes. He formulated a federalist project that is usually called the Jagiellonian concept ${ }^{18}$ or federation model, taking into account the facts that he was dealing with:

1. Russian imperialism, which did not ignore losing large parts of territories.

2. Lithuanian and Ukrainian nationalism.

3. Strong and serious Germany despite the defeat.

4. Practical inability to create the ethnic boundaries of the former territories of the Republic of Poland. ${ }^{19}$

\section{THE HUNGARIAN AND POLISH INITIATIVES IN THE INTERWAR PERIOD}

Right after the end of the First World War, in 1920s Poland was still at war against Bolshevik Russia to gain back more territories in the East. Thanks to many reasons, including the Polish army and partly the international contribution, among others the assistance and the help coming from the Hungarians, the Miracle on the Vistula in August 1920, the Polish army could push back the Russian troops. The question was whether Poland succeeded in preserving its independence at the end of the First World War, establishing its eastern borders and whether it was possible to defend Europe from

16 A. Schmidt, "Piast vagy Jagello? Lengyelország és Európa”, in Z. Bretter, V. Glied, Z. Vörös (eds.), Az elkötelezett tanitó. Tiszteletkötet Csizmadia Sándor 65. születésnapjára, Pécs 2012, pp. 119-125.

17 From the Memorandum that was completed as a reaction to the Russian position in the Russian-Japanese war.

18 F. Ejdus (ed.), Memories of Empire and Entry into International Society. Views from the European Periphery, London-New York 2017, p. 84-88.

19 S. Williamson, "Choosing an Ethnic Group to Target: The Case of the Jewish Minority in Interwar Poland”, Germina Veris, vol. 1, no. 1 (2014). 
Soviet Russia's plan to revive the flame of revolution and to bolshevize all of Europe in Germany.

The support from Western European countries was not crucial in the Polish-Bolshevik war as Western allies played a minor intermediary and supportive role. Under the pressure of Bolshevik propaganda and the left-wing parties in Europe, between July 10, and August 25, 1920, Poland could only count on French ammunition that had been transferred to Hungary. In the summer of 1920, the Hungarian government wanted to achieve three goals when it came to the final, decisive phase of the Soviet-Russian-Polish war; to help Poland, to stop the Russian expansion and to help the Poles to assist at least part of the Trianon borders. (This was part of the secret Hungarian-French negotiations in Paris. $)^{20}$ France agreed on the condition that the armed if the Prague Government contributes to the transfer through its territory. ${ }^{21}$

The Western-allied forces finally were much more on Pilsudski's plan as the Polish-Bolshevik war was a possibility to stop the spread of Communist ideology in the West and to interfere in the revolution in Germany. Although Ukraine was fighting frequently for its independence, it never gained support from the Western powers. As the Ukrainian lands were occupied several times from different directions, in 1921 at the Treaty in Riga Ukraine, Belarus and Lithuania were divided between Poland and Bolshevik Russia. As the consequence of this treaty, the structure built out in this part of Central and Eastern Europe that served as core for the further conflicts.

With the success of the war, Piłsudski's position strengthened and he could focus on the further visions of federalist Central Europe. The natural consequence could have been a Polish-Lithuanian federalist cooperation, however, the Treaty in Riga with the new borders made the compromise impossible. Poland and Lithuania interrupted their previously existing ties, even diplomatic relations. Regarding the extension of the Polish borders, Piłsudski wanted a strong Poland but his Poland would have significant minorities of Germans, Ukrainians, Belarussians, Lithuanians - comprising forty percent of the population. Pilsudski, however, was willing to contemplate a federation in which the Lithuanians, perhaps, or the Ukrainians, would work with Poles as equals. MacMillan argues Pilsudski recognised that he needed some support from the Allies. As he remarked There cannot be independent Poland without an independent Ukraine, but on the other hand he was also aware of the fact that all we can gain in the west depends on the Entente - on the extent to which it may wish to squeeze Germany while in the east doors that open and close, and it depends on who forces them open and how far. The geopolitical situation, as well as the very existence of a young country, was threatened by its close and strong neighbours - the Soviet Russia and Germany. ${ }^{22}$

20 L. Varga, Egy emléktábla és ami mögötte van. Lengyelek-magyarok, 1919-1920, at <http://www. hitelfolyoirat.hu/sites/default/files/pdf/29-34_0.pdf>.

21 As we know, the answer was not correct, as it did not want to give up on a piece of the great Hungarian land.

22 M. MacMillan, Paris, 1919. Six Month that Changed the World, New York 2002. 
His vision also focused on a federation or alliance with Balkan and Baltic states and envisioned the Central European Union including Czechoslovakia, Hungary, Romania, Yugoslavia, Greece, however, the territorial claims among the potential members hindered this effort. Hungary had territorial claims towards the new neighbouring independent states including Yugoslavia, Romania, and Czechoslovakia while the connections between Poland and Lithuania were also problematic. Tense PolishLithuanian relations did not permit the establishment of the union, particularly when Piłsudski talked about the integration of Lithuania with Poland. The only effective cooperation was established in 1921 between Poland and Romania that also determined the future of the Hungarian and Polish relations. Thus, this attempt to revise geopolitical arrangements of the Eastern Europe was not successful and Piłsudski's intention to restore Poland in the form of great power, equivalent to Russia, failed too.

Hungary appeared in agenda of the Polish diplomacy repeatedly in the 1920s as Poland initiated a new form of integration. Creation of the basis for Międzymorze (Intermarium) project, which has been seen in the close cooperation between Poland, Hungary, and Romania that was questionable. On the other hand, Polish-Hungarian relations have been positively affected especially by their common hostility to Czechoslovakia. Creating a common Polish-Hungarian border after the break up of Czechoslovakia did not have any significant effect on the geopolitical preconditions for implementation of the Międzymorze concept. Relations with Romania have been affected by its different interests and its membership in the Little Entente. After its breakup, Romania was focused on the cooperation with Germany. The failure of the Polish rapprochement with Hungary and Romania reduced the importance of the Balkan States for building the compact partnership of the Międzymorze concept. The improving contacts with Latvia and Estonia did not bring the desired effect. Other Scandinavian countries have been reluctant to engage themselves in the complicated Central European issues.

The Polish and Hungarian relations reached a new milestone in the late 1930s. As Józef Beck, the minister of foreign affairs was working on a new foreign policy of the Polish government balancing between the Bolshevik Soviet Union and the Nazi Germany, firm collaboration between Poland and the smaller countries of Central Europe became urgent. This concept was promoted especially during the tense years of $1937-1939 .{ }^{23} \mathrm{In}$ his initiative, called 'Third Europe' Beck based his policy on a pragmatic calculation of geopolitical changes in Europe during the 1930's when two power blocks started to form: the fascist block led by Germany and the block of Western powers, led by Great Britain and France. Therefore, according to him, it was necessary to create the third group of the Central European States, which could become 'the Third Europe.24

From the security of the territorial integration of Central East Europe, both Piłsudski and Beck were convinced that the region became fragmented because of

23 As Kornat remarks the principle that politics is very difficult to reconstruct and J. Beck has never explained its principles. Similarly, his opinion about the territorial scope of Międzymorze has not been fully clarified.

24 As Ištok and Koziak remark, Beck did not consider the Soviet Union - Russia as a European power. 
a number of small countries, which are only a subjects of external power. Therefore it is necessary to pool their potential under the natural leadership of Poland. The pragmatic Beck focused rather on security than ideology and this perception led him to the assumption that cooperation would be necessary regardless the political orientation of the ruling governments. Beck saw the solution is the grouping of states between the Baltic, Black, and the Adriatic seas. These states were, as well as Poland, also threatened by the two dominant powers - Germany and the Soviet Union. Poland should stand at the forefront of the group, which would hamper the imperial ambitions of powerful neighbours. The Międzymorze concept did not count with the inclusion of Austria and Czechoslovakia. One of the reasons for that was an assumption that these countries would be objects of the German expansion soon and therefore they cannot be considered as permanent geopolitical entities in the Central Europe. In case of Czechoslova$\mathrm{kia}$, there were also other reasons stemming from its geopolitical position and its problematic relation with Poland. As Ištok and Koziak remark, the potential participants of the Międzymorze concept were those countries which were located south of the Polish political borders but Poland strived to present itself as the most reliable defender of the Slavic patriotism.

During the 1930s, Polish politicians tried to manoeuvre between Hitler's Third Reich and the Soviet Union. On July 25, 1932, Poland and the USSR signed a nonaggression pact. As a consequence, the Polish government somewhat slowed down its activities with regard to the Promethean movement, without shutting them down, however. ${ }^{25}$ The centre of planning and directing was now transferred from various ministries, who had divided the work among themselves, to the Second Department of the Second General Staff. In 1934, Piłsudski’s Poland concluded a non-aggression pact with Nazi Germany.

From the Czechoslovakian perspective, the concept itself was significantly weakened by ignoring Czechoslovakia with its industrial and military potential. However by the late 1930s, based on the negotiations in Munich, the Polish diplomacy also began to share the view that Czechoslovakia would not preserve its territorial integrity. The Polish initiatives were accepted as uncertain. The controversial connections between Poland and Lithuania weakened the possibility of cooperation while several politicians from Western Europe treated the concept as a sign of Polish imperialism or chauvinism. ${ }^{26}$ In the area of Southeast Europe and the Balkans, the Miecdzymorze project clashed with the geopolitical objectives of the Little Entente and Italy. However, the efforts to create a grouping of states in the area of Central Europe led by Poland collid-

25 The Promethean Movement was an anticommunist international, designed to destroy the Soviet Union and to create independent states from its republics. [...] It brought together grand strategists of Warsaw and exiled patriots whose attempts to found independent states had been thwarted by the Bolsheviks. Symon Petliura and his exiled Ukrainian People's Republic joined forces with other defeated patriots from the Caucasus and Central Asia. [...] Prometheanism was supported by European powers hostile to the Soviet Union, morally by Britain and France, politically and financially by Poland - T. Snyder, Sketches from a Secret War. A Polish Artist's Mission to Liberate Soviet Ukraine, New Haven 2005, pp. 40-41. 
ed especially with the interests of Germany, which were presented under the long-term geopolitical code of Mitteleuropa.

Although the breakup of Czechoslovakia created the common Polish-Hungarian border which was the help for the realization of the Międzymorze project, the subsequent course of events deprived Poland of any chance to push for its own geopolitical concepts.

Right after the Munich agreement but acting independently of the four great powers, Poland's foreign minister, Józef Beck was able to force Czechoslovakia to accept Polish territorial demands in the so-called Trans-Olza Teschen district. The aim of the Polish politician was to open a common Polish Hungarian border. Beck realised that the acquisition of this territory was hardly sufficient to compensate Poland for Germany's increase of power in Central Europe. The establishment of a Neutral Security Bloc was the best solution after France's and Great Britain's withdrawal from Central Europe. The first step towards such a bloc was obviously a common Polish Hungarian frontier. Beck feared that all South-Eastern European states would eventually become vassals of Germany further imperilling the security of Poland. If however, Poland was able to establish a compact block of states under her leadership, then, he reasoned, there was a better chance for his policy of equilibrium in regard to Germany and the Soviet Union to succeed, assuring Poland's sovereignty as well as the independence of the other states. He wanted Slovakia to be set up as an independent state under Polish and Hungarian protection, and Sub-Carpathian Ruthenia to be annexed by Hungary. Beck thought about this idea already in 1936 of setting up Slovakia as a neutral buffer state under Polish protection but where Hungarian influence especially economic would be present in the event of Czechoslovakias disintegration under German pressure. As far as sub-Carpathian Ruthenia was concerned, Beck favoured its annexation by Hungary. The incorporation of Czech lands by Germany, however, rewrote the plans. As far as the original ideas were concerned, Beck's plans related to the re-establishing of Central Europe failed because of several reasons:

1. The Romanian partner was disappointed as with the incorporation of Sub-Carpathian Ruthenia by Hungary the Czech and Romanian common frontier was not a reality anymore. The original Czech and Romanian frontier was deleted and the rail connection between the two states that was beneficial for iron and steel transportation was suspended.

2. The Hungarian claims towards the lost Slovakian territories were greater than it was affordable.

3. It became clear that such a fragile system could mean the dissolution of Petite Entente as a final proof.

However, Beck's plan could be understood as a possibility to establish a Polish-led security system in the Danubian basin. ${ }^{27}$

The Hungarian politicians asked for Polish assistance in the Hungarian and Slovakian territorial disputes. Several discussions were held with the participation of the

27 T. Gromada, Essays on Poland's Foreign Policy, 1918-1939, New York 1970. 
representatives of the Hungarian, Czechoslovakian and Polish diplomacy. In late spring the negotiations with the participation of János Esterházy, the Hungarian minister of foreign affairs focused on the possibility of a potential Catholic Slovakian-Polish-Hungarian bloc against the increasing threats from Germany. In May 1938 these discussions focused on the consequences of the dissolution of Czechoslovakia and the potential support of the Hungarian aims towards Slovakian territory and the potential Polish support of the Hungarian territorial claims with the guarantee of the rights of the Slovakian nation guaranteed a wide autonomy. ${ }^{28}$ The Munich treaty signed in late September 1938 by the representatives of British, French, Italian and German governments resulted in the dissolution of Czechoslovakia emphasizing the German aims to protect the Sudeten German ethnic minority groups' rights. However, it resulted in the dissolution of Czechoslovakia, the annexation of Czech and Moravian lands by Germany and a smaller part by Poland. As the reference point of the negotiations in Munich was the ethnic issue that determined the potential outcomes of the Hungarian claims towards the lost territories. Based on the experience of the Austrian Anschluss with the ethnic character the Hungarian moderate politicians had to modify their previous ambitions regarding the potential federative unification of lost territories of the Carpathian basin in a federalist way under Hungarian leadership. The decision of the Slovakian People's Party in 1938 October in Zilina made it clear for the Hungarian politicians that there was no reason to return back to the Hungarian Kingdom. With this rejection, the Hungarian politicians could trust only the returning back to the Ruthenian lands based on Wilson's principles of self - determination. The Vienna Award in November 1938 made the Hungarian and Ruthenian cooperation impossible. However the common Hungarian and Polish border after the annexation of Trans-Carpathian region by Hungary in 1939 spring re-established the common Hungarian and Polish border. ${ }^{29}$

28 Beck even offered Warsaw as the potential venue of the Slovakian and Hungarian negotiations, however, this effort was useless as the Slovakian partner withdrew from any further negotiation regarding the unification with Hungary based on any type of autonomous status. The Slovaks don't want the Hungarians. They don't trust them, there is no word about returning to Hungary. Slovaks survived the Romans, the Huns, the Magyars, and the appearance of other tribes. We survived and will survive - remarked the Sidor.

29 Actually, this existing Polish-Hungarian common border helped the Polish government to leave Poland after the German occupation and the break out of the Second World War. 
Figure 2 .

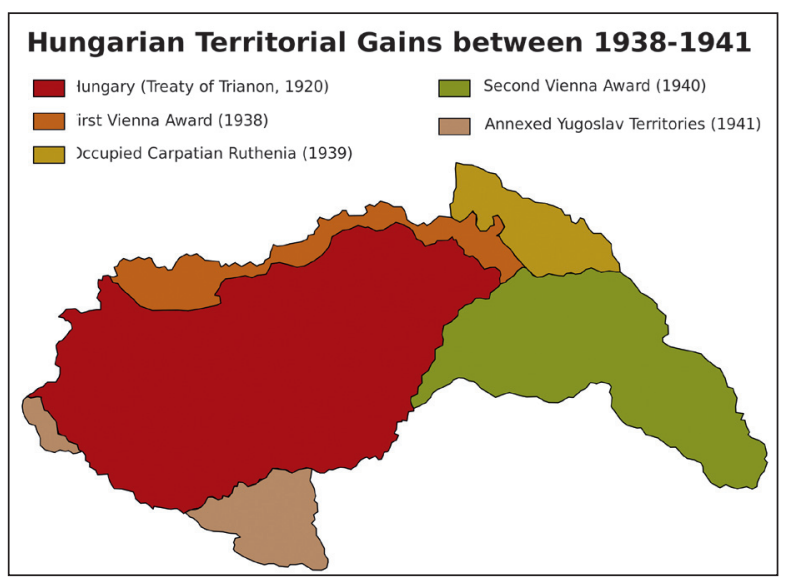

Source: "Putin Ponders Border Revision between Hungary and Romania", Hungarian Free Press, 5 September 2016, at <http://hungarianfreepress.com/2016/09/05/putin-ponders-border-revision-betweenhungary-and-romania/>.

The original Ruthenian aims focused on a potential Hungarian-Ruthenian union that failed after the decision in Vienna. The Hungarian conservative, legitimist, liberal and social democratic politicians all were disappointed with the decision and emphasized the necessity of the close cooperation of Hungary with Poland in order to strengthen the counterbalance against the increasing German threats. The Hungarian foreign policy focused on a balanced relation between Hungary and Italy as they saw the opportunity of struggling against the German supremacy but these political circles also aimed the good relations between Hungary and France and Great Britain. The president of the Hungarian Independent Smallholders' Party, Tibor Eckhardt ${ }^{30}$ even declared that the guarantee of the safety of Hungary is based on the common Hungarian and Polish border. The German support of the Ruthenian aims towards independence was seen suspicious among Polish politicians. The German efforts of treating Ruthenia as a potential Piedmont for Ukrainians threatened the Polish territorial integrity as in Eastern Poland there lived more than 6 million Ukrainians whose intention was the establishing of a great-Ukrainian state.

The Polish-Hungarian relations had to face challenges in early 1939. Beck's vision about the Warsaw-Rome axis seemed to be less and less feasible while Germany's position strengthened. Poland's geopolitical position, the collapsing Czechoslovakia, the isolated Hungary and the pending Italy was extended with the disinterest from France

30 Eckhardt was the member of the Hungarian parliament since the 1920s. In the late 1930s early 1940s, he was a negotiator of Hungary sent to the USA by Teleki Pal, the Prime Minister to discuss with the Anglo-Saxon powers to counterbalance the German domination in Hungary. After the Second World War, he did not return back to Hungary and remained one of the key figures of the Hungarian politicians in exile. 
and Great Britain. The German standpoint regarding the position of Poland remained unchanged as even in 1939 March Germany still has not lost the hope to establish a German-Polish alliance against the Soviet Union. Basing on this agreement Germany offered assistance in giving parts of Slovakia both to Poland and Hungary.

The occupation of Trans-Carpathian region in the spring of 1939 and the common Polish and Hungarian border was welcomed in Western Europe. Both the British and French ministers of foreign affairs were delighted that Hungary intervened as regarded the extension of the German influence in Central and Eastern Europe. This Hungarian step was warmly welcome in Poland and the spring of 1939 seemed to be the victory of Beck's vision on Third Europe. However, in May this optimistic vision disappeared. The tension between Poland and Germany increased and as Beck joined the English and French alliance neglecting the cooperation with Germany the summer of 1939 became quite hectic both for Poland and for Western Europe. In August 1939, the Ribbentrop-Molotov agreement led to the Second World War, and Poland disappeared from the political map of Europe again. The vision of the cooperation within the frames of Central and Eastern European states seemed to become unreal partly because of the increasing threat from Germany and partly because of the unfeasibility of the majority of the governments and last but not least because of the territorial changes. The plans on re-establishing Poland and the initiatives on further cooperation could be discussed among the representatives of the governments in exile with new actors.

The Polish government-in-exile, which was based in London since 1940, again took up the concept of the Intermarium federation in a somewhat altered form. General Władysław Sikorski picked up his ideas for a federation as the head of the government-in-exile. In a memorandum he submitted to US President Franklin Roosevelt in December 1942, he proposed the formation of a Central European Federation. This federation, according to Sikorski, was necessary in order to provide for the economic existence and, therefore, also of the security of the states along the Belgrade-Warsaw axis. A federation based on strong foundations will be a guarantee likewise of the security of the United States, both in relation to Germany and also to any other forces which might again bring Europe to a state of chaos and, consequently, of war. According to our conception, the basic elements of the federation include Poland (with Lithuania), Czechoslovakia, Yugoslavia, Greece (and Hungary). ${ }^{31}$ The inclusion of Hungary to a potential Central European federation, however, was still in Sikorski's plans in 1940 but in accordance with a close cooperation with Czechoslovakia for the future. In August he began the secret negotiation with Benes who was that time the head of the Czechoslovakian government in exile in London. This plan was strongly opposed by the Soviet Union, whose support in the operations against Germany became very important for Great Britain. When in 1943 Eden, the British Minister of Foreign Affairs met his colleague from the Soviet Union, Molotov and shared the plans for Central and Eastern Europe Molotov expressed his

31 S. Meiklejohn Terry, Poland's Place in Europe. General Sikorski and the Origin of the Oder-Neisse Line, 1939-1943, Princeton 2014, p. 4. 
objection as - according to his opinion - the aim of this cooperation is the isolation of Soviet Union. ${ }^{32}$

From the Hungarian perspective, this proposal was hardly realistic because of Hungary's strong German orientation. In 1939 the Polish and Hungarian connections were good enough to ensure the Hungarian neutrality towards German aggression in Poland by refusing the use of Hungarian railroad system for military transportation but assisting in the opening of common Polish and Hungarian border in front of Polish refugees, and in 1940 a Polish secondary school was established in Balatonboglár, functioning until the German occupation of Hungary in 1944. In the first years of the Second World War Hungary wanted to continue a balanced and rather neutral foreign policy in accordance with the general aim, the peaceful revision of the lost territories. The plans for establishing a Hungarian government in exile in the USA were failed in 1940 despite the promise Pál Teleki, the Hungarian Prime Minister got from the British partner regarding the acknowledgement of the Hungarian government in exile by the British government and its efforts against Germany at a potential peace conference after the end of the Second World War. ${ }^{33}$ The 5 million USD that was originally transferred to the USA to create the financial basis of the Hungarian government in exile was withdrawn back to Hungary in 1940 and after the second Vienna Award when a great part of the lost Hungarian territories in Northern Romania was given back to Hungary the German orientation increased. In 1941 April Teleki committed suicide and the new prime minister, László Bárdossy made further steps towards Germany and Hungary terminated diplomatic relations with Great Britain and declared war both on the Soviet Union and the USA. ${ }^{34}$

By 1943 the potential federalist Central Europe based on the close cooperation between Czechoslovakia and Poland failed as Benes began secret negotiations with Stalin in order to achieve support for their aims for territorial integrity.

As the Polish vision for the cooperation did not seem to be realistic it is essential to mention the Hungarian vision that was also ambiguous. Apart from the Polish visions on the Central and Eastern European region, Hungarian politicians also composed their views for the future of this region. The backbone of these plans of cooperation was the active participation of Romania and Hungary in it. As Poland and Romania had good relations in the interwar period this idea would have met the sup-

32 As Ormos remarks, this objection from Molotov was in accordance with the changing position of the Soviet Union in the war against Germany. By that time the battle under Stalingrad stopped the German invasion and the Russian victory had symbolical meaning. The Soviet politicians treated Central and Eastern Europe as their potential sphere of interest and therefore they were strongly against any kind of federalist concept, in particular with the support of the Western Allies. M. Ormos, Közép-Európa. Volt? Van? Lesz?, Budapest 2007, p. 198.

33 None of the CEE exile governments' efforts was acknowledged after the end of the Second World War as the entire region became the sphere of interest of the Soviet Union based on the agreement in Yalta.

34 A.D. Bán, “Az összeköttetés megszakad. Brit-magyar kapcsolatok 1938-1941”, RUBICONline, 19 January 2018, at <http://www.rubicon.hu/magyar/oldalak/az_osszekottetes_megszakad_brit_magyar_ kapcsolatok_1938_1941>. 
port from Polish politicians, too. The Hungarian plans operated with a trilateral cooperation among Romania, Transylvania, and Hungary and the hope that the joining of the strong Polish state could definitely increase stability both in economic and issues related to security in this region. Hungarian politicians with the former Prime Minister, István Bethlen on the lead insisted on two issues - leaving out Czechoslovakia and Austria. The idea of leaving out Czechoslovakia from this cooperation based on the Hungarian assumption that Slovakia should remain an integral part of Hungary (that was actually a part of Czechoslovakia until 1938) and the fear that since the Anschluss, Austria seemed to be equal with Germany. Based on historical experience Hungary did not support the idea of any joint Austrian-Bavarian and Hungarian cooperation, however, as Bethlen remarked the presence of German economy in this region was necessary as a potential partner. ${ }^{35}$

Following the end of the Second World War, Stalinist bureaucracy extended the property relations of the October revolution in a military and bureaucratic way to Eastern Europe. Although the Allies had agreed upon this division of spheres of influence in order to safeguard bourgeois rule on a world scale, the deformed satellite states that emerged in the post-war period never ceased to be a thorn in the side of imperialism. In the covert warfare against the Soviet Union, the imperialist powers based themselves to a significant degree on the mobilization of those forces that had been part first of the Intermarium and then those war networks that were against the Soviet Union during World War II. Most of the Polish elites and nationalist intelligentsia had left the country by 1948 when the Polish People's Republic was proclaimed. Sections of these layers continued to promote the Promethean project. In Paris, the most significant Polish émigreé journal, Kultura, edited by Jerzy Giedroyć, openly advocated Piłsudski’s Intermarium strategy. The necessity of restructuring of the CEE region had great importance among the representatives of Hungarian politicians in exile. Ferenc Nagy, the Prime minister of Hungary between 1946 and 1947 played an important role in the discussion on Central and Eastern Europe, however, the Hungarians and Romanians in exile worried about the Slavic dominance in any cooperation initiated by Poland. ${ }^{36}$

\section{THE REDRAWN CENTRAL AND EASTERN EUROPE AND THE NEW PLANS FOR COOPERATION}

Until the last years of Socialism, the foreign policy and the national orientation of the members of the Soviet Bloc were subordinated to the Brezhnev Doctrine. As the whole Central and Eastern European region belonged to the sphere of interest of the Soviet

\footnotetext{
M. Ormos, Közép-Európa..., p. 170.

36 "Emphasis (1968: The University of Alabama), Ferenc Nagy discusses America and the future of East Central Europe", Acumen - The University of Alabama Libraries' Digital Archives, at <http://acumen. lib.ua.edu/u0008/0000001/0000017/ ?page $=18$ limit $=40>$. In his speech he expressed his worry about the recent situation of the socialist states being satellite states of the Soviet Union.
} 
Union it was hardly possible to discuss any kind of cultural, ethnic or even religious cleavages. However, especially from the second half of 1980s new discussions began about the structure of Europe. With the collapse of the bipolar system the member states of the socialist bloc were searching for orientation and in order to replace the political and economic vacuum the establishing of Visegrad Group in 1991 was a particular answer to this specific situation. The cooperation, which was established in particular to express the common interest of the members aimed the European and the North-Atlantic integration at first and to strengthen the economic and cultural cooperation in this region. The EU and NATO membership as the final aim were achieved by 2004 . Despite the original principles, the Visegrad Group is still active, it celebrated the $25^{\text {th }}$ anniversary in 2016 and within these 25 years, it managed to redefine itself several times.

The Polish and Hungarian foreign policy and national interests were similar after the political transformation. Apart from being the members of NATO, the European Union and the Visegrad Group the heads of the diplomacy and the governments traditionally had a good connection. The Polish foreign policy was supportive towards the Euro-Atlantic integration and the Polish foreign policy was rather West-orientated. Comparing the Polish and Hungarian orientation the Hungarian case was much more EU-sceptic in particular since the FIDESZ government that was formulated in 2010 and was re-elected in 2014. The basis of the traditional Hungarian and Polish friendship based on the common historical past and the similarities in political culture. Even if there was any difference in the governments, i.e. left-wing or right-wing parties were in ruling position this traditional cooperation was not suspended. In 2015 recalled changes in the bilateral relations between Poland and Hungary as after eight years of governance the Civic Platform (Platforma Obywatelska, PO) lost both the presidential and the parliamentary elections as both cases the Law and Justice (Prawo i Sprawiedliwość, PiS) party won them. After controversial relations between Poland and Hungary between 2010 and 2015 Donald Tusk's government was treated with doubts by the Hungarian partner, Law and Justice Party and the Hungarian FIDESZ revived their friendship. However, a significant contradiction was recognisable between the two party leaders; the Hungarian attitude towards Russia. The landslide victory of Poland's conservative Law and Justice party (PiS) in October 2015 allowed the new political elite in Warsaw to undertake changes at an unprecedented pace. By the end of 2015, both states became the targets of European Union politicians.

With the new Polish government a new approach appeared in Polish foreign policy. Instead of the Western orientation of the past two and a half decades or the traditional responsibility towards the ULB states, Andrzej Duda initiated the orientation that focused on a new direction that called ABC (Adriatic see, the Baltic region and Black sea (Morze Czarne) triangle) policy. ${ }^{37}$ That was treated partly as the revision of the Intermarium plan with some modifications, or the new way of redefining the role of Central

37 “President Starts Official Visit to Hungary", President.pl, 17 March 2016, at <http://www.president. $\mathrm{pl} /$ en/news/art,122,president-starts-official-visit-to-hungary.html>. 
and Eastern Europe located in the Eastern periphery of the European Union. The initiative focused mostly on economic cooperation instead of political federation however faced with doubts and fears.

The Ukrainian crisis and growing fears of Russian actions, combined with anawareness that certain core EU members may not firmly resist Russian aggression in the Black Sea and Baltic regions, has led Poland to look for an alternative regional counterweight. The rethought and changed Intermarium geopolitical concept originally also meant a plan for military alliance spread between the Baltic, Black and Adriatic seas, which was to counter Bolshevik and Stalinist expansion in the 1920s and 1930s. ${ }^{38}$ This new scenario, however, drew a new way of cooperation and the change in orientation from a smaller group of states (the Visegrad Group) to a wider perspective. As the Visegrad states' behaviour towards the EU initiatives and the refugee policy worried many actors the ABC (TSI = Three Seas' Initiative) concept was treated even more controversial.

The Three Seas Initiative that was established in August 25, 2015 originally focused on the cooperation among the signing partners from the Baltic states to the Western Balkan region in order to express their vision on the necessity of cohesion of Central and Eastern Europe within the European Union and to give a new North-South approach to the existing East-West orientation. The member states were also divided by their expectations based on this cooperation. The Baltic States such as Poland saw protection against potential threatens from Russia.

The Hungarian participation in the TSI is rather controversial or at least not openly discussed. The two confusing elements are the anti-Russian approach and the pro-USA standpoint. In these days Hungarian and Russian relations are getting closer at the level of the Hungarian government, while since 2014 the American-Hungarian relations are not at their best.

Generally, if the initiative preserves anti-Russian approach then the intensifying Hungarian-Russian contribution can serve as an obstacle in the Hungarian contribution. Note that the TSI has a special phase regarding the USA participation in the European affairs. In 2017 summer the American president, Donald Trump participated in the meeting of the partner states of the TSI in Warsaw. From the Hungarian standpoint, there is nothing surprising in the traditionally good Polish and USA relations, however, the Orbán government had a troubling and contentious relationship. ${ }^{39}$ As the Hungarian government had an especially bad connection with the Democratic Partyled USA government, greatest expectations were expressed towards the Trump bureau-

38 K. Kraev, "Warsaw pivots to the Black Sea", New Eastern Europe, 28 April 2016, at <http:// neweasterneurope.eu/2016/04/28/warsaw-pivots-to-the-black-sea/>.

39 One of the peaks of the frozen relation between the USA and Hungarian diplomacy was October 2014 when six officially unknown high-ranking public servants were denied entry to the territory of the USA as they were suspected of corruption. Later, also according to unknown sources it became presumable that it affected the formal president of the National Tax and Customs Administration, the Secretary of State of the Prime Minister's office, the formal director of the government-friend Hungarian Think Tank, Századvég and the deputy president of the FIDESZ and the minister of Regional Development. "Hat embert tiltottak ki Amerikából”, Index, 20 October 2014, at <http://index.hu/belfold/2014/10/20/ hat_embert_tiltottak_ki_amerikabol/>. 
cracy. Right before his election, in 2016 the Hungarian Prime Minister expressed his hope towards Trump's victory at the Tusványos Summer University in Transylvania. ${ }^{40}$ The Hungarian behaviour and the open support towards Russia were criticized several times by the USA. The Hungarian politicians from FIDESZ treated these comments as threats from the Democratic Party and turned to the new presidential election with great expectations. This sympathy towards Trump, however, did not fulfil their expectations. Until autumn 2017 the USA president and the Hungarian Prime minister have not participated in a bilateral meeting, there is no word about Trump's visit to Hungary and the Hungarian government has not received any invitation addressed to the Prime minister.

The 2017 meeting of the representatives of the TSI was held in Warsaw with the participation of Donald Trump who gave special importance to this meeting, however the Hungarian state was represented by Janos Áder, the Hungarian president, who, according to the Fundamental law of Hungary has rather a symbolic position. Meanwhile, the Hungarian Minister of Foreign Affairs and International Trade emphasized the importance of the Visegrad Group not paying special attention to the Warsaw summit. ${ }^{41}$

Although the official Hungarian media did not pay specific attention to the TSI, the right-wing radical media ${ }^{42}$ expressed the worries of the consequences, in particular, the exclusion of Russia, the attempts of NATO to extend the influence towards the pending states located between the EU and NATO member states and Russia with a special accent to Ukraine. The critical arguments also mention the potential German reaction towards an USA-led policy focusing on any Polish-led alliance. ${ }^{43}$ As the Hungarian government made some efforts to harmonize its interest with the Russian geopolitical view, the right/wing Jobbik that was previously suspected of Russian orientation, by 2015 autumn also expressed the support towards the establishment of any Central

40 I am not a lobby activist of Mr. Trump and I have to confess that previously I never thought that he would be the better choice for Europe and for Hungary. However, I heard his initiative on how to control terrorism and I recognized that even myself as a European could not have expressed it more precisely - "Orbán elhitte, hogy Trump hálás lesz neki, aztán szembejött a valóság”, TLDR - 444, 20 July 2017, at <https:// tldr.444.hu/2017/07/20/orban-elhitte-hogy-trump-halas-lesz-neki-aztan-szembejott-a-valosag>.

41 We should emphasize that however, the Visegrad Group has got relatively large publicity in the Hungarian media, the Three Seas Initiative has got slightly less interest. The reason can be various. As the Initiative itself mentioned only in few cases, we can base only on preconditions. One of the reasons can be the lack of close Hungarian and USA relations. On the other hand, while if the Initiative can be treated as a gesture in order to isolate Russia then it is understandable that in such a situation when the investment in the Paks nuclear power station depends on Russian loan and the Russian and Hungarian approach can be recognized by the intensity of Vladimir Putin's visits to Hungary.

42 That is supported by the Russian propaganda and expresses predominantly Russian geopolitical vision.

43 “Szándékos destabilizálással válna regionális hatalommá Lengyelország”, Hídfo, 27 November 2015, at <http://www.hidfo.ru/2015/11/szandekos-destabilizalassal-valna-regionalis-hatalommalengyelorszag/ $>$. The extremist website even accuses Poland of the attempts of destabilization of the Russian Federation and indirectly the at least the politically weakening Germany and manipulating the potential partner states in order to become a regional power. 
European alliance not excluding the revival of the Polish Intermarium concept. ${ }^{44}$ The Right-wing orientated, but the moderate newspaper, Magyar Nemzet also dealt with the necessity of a strong cooperation offering the traditional Polish and Hungarian friendship as a backbone of this cooperation. The author of the vision expresses his view as the 70-year-old semi-colonial status of CEE region and the pending position of the CEE EU member states recalls some problem-solving method. ${ }^{45}$

A special element of the TSI is the question of the energy supply of the CEE region. The presence of Trump at the Warsaw meeting was a warning towards Russia as he not only expressed the desire to supply the region with American gas reducing the energy dependence of the entire region from the Russian energy supply. Apart from this he also offered the extension of the sanctions against Russia that was also warmly welcomed by the majority of participants that were either satellite states or were even the parts of the Soviet Union.

The critical approach of the Western European EU member states could be recognized by the attempts to divide and weaken the cooperation in the Visegrad Group. While Poland was engaged in the preparations for Donald Trump's visit, almost at the same time a very important meeting was organised in Slavkov in June 2017. This was the third official meeting of the members of the Slavkov Triangle (Slovakia, Austria and the Czech Republic ${ }^{46}$ ) that is be treated as an attempt to hamper the Visegrad cooperation. At the end of the summit, the participants accepted a declaration in which where they expressed their willingness to extend their cooperation with the French president. Emmanuel Macron who paid the first visit in the CEE region and initiated the meeting with the Prime ministers from Slovakia and the Czech Republic however leaving out the Polish and Hungarian colleagues. With this visit he also had the chance for discussion with the Romanian and Bulgarian partners. Political analysts in Hungary argue that Macron's decision was the proof of the harmonization of French and German cooperation with the extension to the participants from CEE region. ${ }^{47}$ This French standpoint was discussed in Salzburg summit in August 2017.48

44 G. Kardos, “Egész új jövőképpel állt elő a Jobbik, az LMP és a Fidesz”, Mandiner, 6 November 2015, at <http://mandiner.hu/cikk/20151106_kardos_gabor_egesz_uj_jovokeppel_allt_elo_a_jobbik_az_ lmp_es_a_fidesz $>$.

45 A. Kósa, "Berlin, Brüsszel és Moszkva egyszerre aggódik a Három Tenger miatt", Magyar Nemzet, 14 July 2017, at <https://mno.hu/kulfold/berlin-brusszel-es-moszkva-egyszerre-aggodik-a-haromtenger-miatt-2407629>.

46 An initiative coming from Austria focusing on the cooperation of Czech Republic, Slovakia, and Austria, practically the majority of the formal Habsburg Empire leaving out Hungary.

47 “Salzburgi csúcs Orbánék nélkül”, Népszava, 23 August 2017, at <http://nepszava.hu/cikk/1138372salzburgi-csucs-orbanek-nelkul>.

48 I. Szent-Iványi, “Rugalmas elszakadás: Slavkov lesz Visegrád Austerlitze?”, HVG.hu, 15 August 2017, at <http://hvg.hu/itthon/20170815_Rugalmas_elszakadas_Slavkov_lesz_Visegrad_Austerlitze>.Some Hungarian analysts already calculated with the end of the Visegrad cooperation. 
Figure 3. The Three Seas Initiative and the Energy Dependence

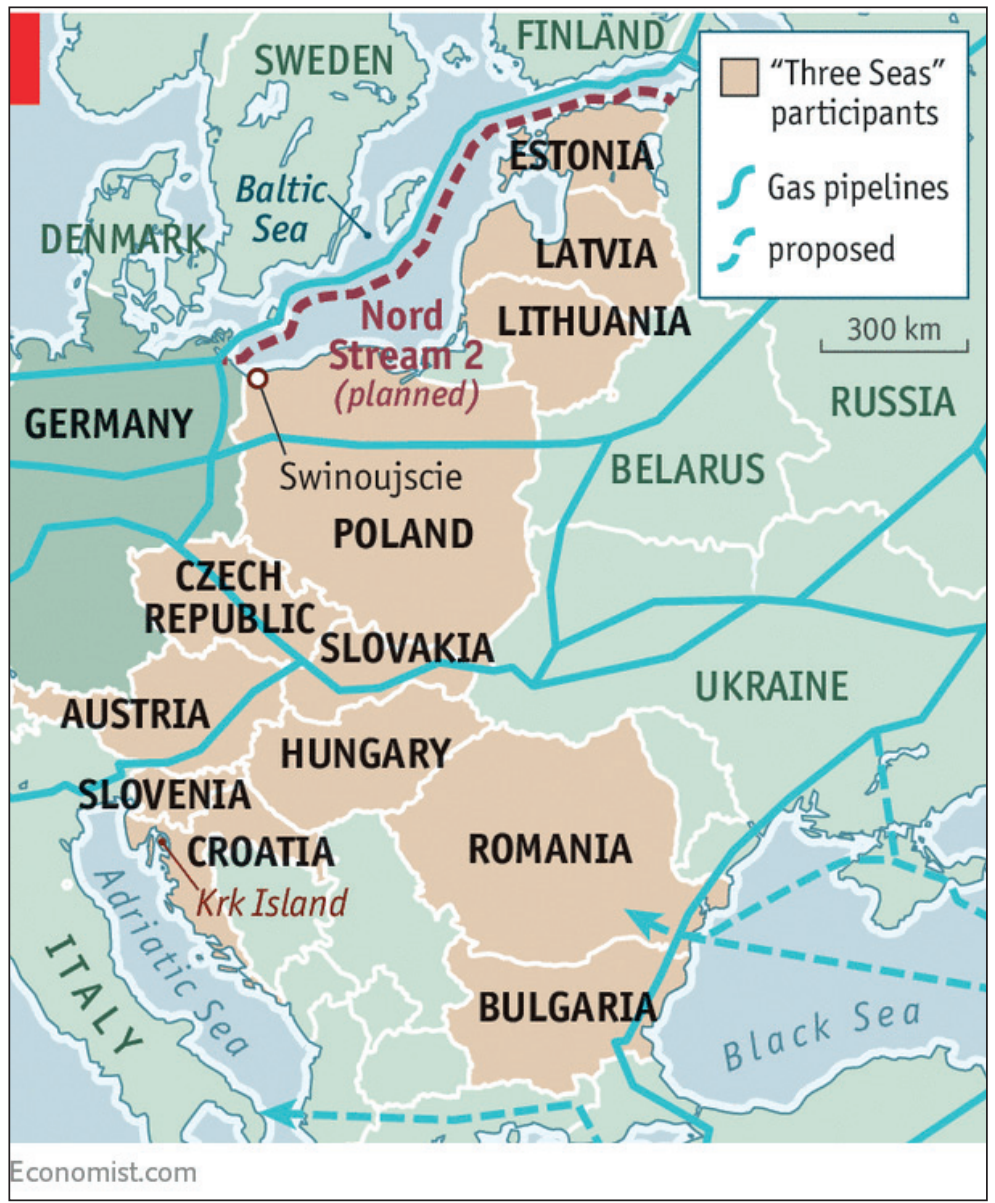

Source: "Germany Fears Donald Trump Will Divide Europe", The Economist, 15 July 2017, at <https:// www.economist.com/news/europe/21725025-angela-merkel-troubled-presidents-chumminess-putinand-poland-germany-fears-donald $>$.

\section{CONCLUSION}

The Polish and Hungarian initiatives for cooperation served as reference points in the $20^{\text {th }}$ century. Despite the fact that the two states were fighting in the two World Wars on different sides they were willing to focus on common interest and tighter their relations. The troublesome years of the Cold War linked them closer to each other as both among the politicians in exile and the underground oppositional circles had a strong connection. The Polish methods for information exchange served a good example for the developing Hungarian alternative groups while the results of the Polish parliamen- 
tary elections and the governing party formations always served as a litmus paper for the Hungarian politicians and experts. The famous phrase 'Varsovian Express' had an additional meaning representing the changes of political orientation in Poland and its effect in Hungary. Nowadays these two states face difficulties in self-representation. Being members of the European Union and the NATO can determine our international orientation, however, our geopolitical position did not change in the past decades and the two powerful neighbours remained the same. The frames of cooperation and the potential partners are various and the tasks of the Polish foreign policy are similar as they were in the interwar period - to find the adequate balancing methods and the partners to these efforts. The Polish initiatives regarding the future of the weaker EU member states show a curved mirror to the old members reminding them of the troubles and challenges of the $21^{\text {st }}$ century.

\section{BIBLIOGRAPHY}

Appelbaum A., Kelet és Nyugat között - Európa határvidékén, Budapest 2016.

Bán A.D., "Az összeköttetés megszakad. Brit-magyar kapcsolatok 1938-1941", RUBICONline, 19 January 2018, at <http://www.rubicon.hu/magyar/oldalak/az_osszekottetes_megszakad_ brit_magyar_kapcsolatok_1938_1941>.

Bialasiewicz L., "Another Europe: Remembering Habsburg Galicja”, Cultural Geographies, vol. 10, no. 1 (2003), at <https://doi.org/10.1191/14744744003eu258oa>.

Bialasiewicz L., "Reordering Europe's Eastern Frontier. Galician Identities and Political Cartographies on the Polish-Ukrainian Border", Manuscript, 1999.

Breuilly J., Nationalism and the State, Chicago 1985.

Davis F., "Europe's Natural Borders", Banging on about the Smoking Ban, 23 May 2016, at <https://cfrankdavis.wordpress.com/2016/05/23/europes-natural-borders/>.

Ejdus F. (ed.), Memories of Empire and Entry into International Society. Views from the European Periphery, London-New York 2017.

"Emphasis (1968: The University of Alabama), Ferenc Nagy discusses America and the future of East Central Europe", Acumen - The University of Alabama Libraries' Digital Archives, at $<$ http://acumen.lib.ua.edu/u0008/0000001/0000017/?page=1\&limit $=40>$.

"Germany Fears Donald Trump Will Divide Europe", The Economist, 15 July 2017, at <https:// www.economist.com/news/europe/21725025-angela-merkel-troubled-presidentschumminess-putin-and-poland-germany-fears-donald $>$.

Gromada T., Essays on Poland's Foreign Policy, 1918-1939, New York 1970.

"Hat embert tiltottak ki Amerikából", Index, 20 October 2014, at <http://index.hu/ belfold/2014/10/20/hat_embert_tiltottak_ki_amerikabol/>.

Hechter M., Containing Nationalism, Oxford-New York 2000.

Hroch M., "From National Movement to the Fully Formed Nation; The Nation Building Process in Europe", in G. Balakrishnan (ed.), Mapping the Nation, London 1996. 
“The 'Innocent' Poland”, Holocaust and WWII in the East, 2 February 2015, at <https:// universalcuriosity.wordpress.com/2015/02/02/the-innocent-poland/>.

Ištok R., Koziak R., "Międzymorze as a Polish Geopolitical Concept", Folia Geographica (Prešov), no. 14 (2009).

Kardos G., "Egész új jövőképpel állt elő a Jobbik, az LMP és a Fidesz”, Mandiner, 6 November 2015, at <http://mandiner.hu/cikk/20151106_kardos_gabor_egesz_uj_jovokeppel_allt_ elo_a_jobbik_az_lmp_es_a_fidesz $>$.

Kornat M., "Realna koncepcja czy wizja ex post? Polska idea 'Trzeciej Europy' (1937-1938)”, in J. Kloczkowski (ed.), Geopolityka i zasady. Studia z dziejów polskiej myśli politycznej, KrakówWarszawa 2010.

Kósa A., "Berlin, Brüsszel és Moszkva egyszerre aggódik a Három Tenger miatt”, Magyar Nemzet, 14 July 2017, at <https://mno.hu/kulfold/berlin-brusszel-es-moszkva-egyszerre-aggodik-aharom-tenger-miatt-2407629>.

Kraev K., "Warsaw pivots to the Black Sea”, New Eastern Europe, 28 April 2016, at <http:// neweasterneurope.eu/2016/04/28/warsaw-pivots-to-the-black-sea/>.

Lefebvre H., The Production of Space, Oxford 1991.

MacMillan M., Paris, 1919. Six Month that Changed the World, New York 2002.

“Magyarországon a XX. században - Magyarország népessége”, Magyar Elektronikus Könyvtá, at <http://mek.oszk.hu/02100/02185/html/171.html>.

Mariani M., Barron P. (eds.), Terrain Vague. Interstices at the Edge of the Pale, London 2013.

Meiklejohn Terry S., Poland's Place in Europe. General Sikorski and the Origin of the Oder-Neisse Line, 1939-1943, Princeton 2014.

Nowak A., "Geopolityczne koncepcje Józefa Piłsudskiego”, Ośrodek Myśli Politycznej, 21 November 2008, at <http://www.omp.org.pl/stareomp/indexb118.html>.

“Orbán elhitte, hogy Trump hálás lesz neki, aztán szembejött a valóság”, TLDR - 444, 20 July 2017, at <https://tldr.444.hu/2017/07/20/orban-elhitte-hogy-trump-halas-lesz-neki-aztanszembejott-a-valosag $>$.

Ormos M., Közép-Európa. Volt? Van? Lesz?, Budapest 2007.

"President Starts Official Visit to Hungary", President.pl, 17 March 2016, at <http://www. president.pl/en/news/art,122,president-starts-official-visit-to-hungary.html>.

“Salzburgi csúcs Orbánék nélkül”, Népszava, 23 August 2017, at <http://nepszava.hu/ cikk/1138372-salzburgi-csucs-orbanek-nelkul>.

Schmidt A., "Kulturális törésvonalak és regionális identitás Lengyelországban", Acta Sociologica, vol. 5, no. 1 (2012).

Schmidt A., "Piast vagy Jagello? Lengyelország és Európa”, in Z. Bretter, V. Glied, Z. Vörös (eds.), Az elkötelezett tanitó. Tiszteletkötet Csizmadia Sándor 65. születésnapjára, Pécs 2012.

Seton-Watson H., Eastern Europe between Two Wars, 1918-1941, Cambridge 1945.

Silberman M., Till K.E., Ward J. (eds.), Walls, Borders, Boundaries. Spatial and Cultural Practices in Europe, New York-Oxford 2012.

Snyder T., Sketches from a Secret War. A Polish Artist's Mission to Liberate Soviet Ukraine, New Haven 2005. 
“Szándékos destabilizálással válna regionális hatalommá Lengyelország”, Hídfo, 27 November 2015, at <http://www.hidfo.ru/2015/11/szandekos-destabilizalassal-valna-regionalishatalomma-lengyelorszag/ $>$.

Szent-Iványi I., “Rugalmas elszakadás: Slavkov lesz Visegrád Austerlitze?”, HVG.hu, 15 August 2017, at <http://hvg.hu/itthon/20170815_Rugalmas_elszakadas_Slavkov_lesz_Visegrad_ Austerlitze>.

“The Three Seas Initiative: Central and Eastern Europe Takes Charge of its Own Destiny", Visegrád Post, 28 August 2016, at <https://visegradpost.com/en/2016/08/28/the-threeseas-initiative-central-and-eastern-europe-takes-charge-of-its-own-destiny $>$.

"Treaty of Trianon", Europe between East and West, at <https://europebetweeneastandwest. files.wordpress.com/2014/07/treaty-of-trianon-this-map-shows-the-vast-consequences-ofthe-paris-peace-settlement-for-historic-hungary.png?w=584>.

Varga L., Egy emléktábla és ami mögötte van. Lengyelek-magyarok, 1919-1920, at <http://www. hitelfolyoirat.hu/sites/default/files/pdf/29-34_0.pdf >.

Williamson S., "Choosing an Ethnic Group to Target: The Case of the Jewish Minority in Interwar Poland”, Germina Veris, vol. 1, no. 1 (2014).

"Winston Churchill Quotes", QuoteAuthor, at < http://www.quoteauthors.com/winstonchurchill-quotes/>.

Zarycki T., "Eastern Poland in a Center-Periphery Perspective”, in M. Stefanski (ed.), Strategic Issues of the Development of the Lublin Region, Lublin 2011.

Zarycki T., Ideology of Eastness in Central and Eastern Europe, London-New York 2014.

Andrea SCHMIDT PhD Hab is Asssociate Professor at the University of Pecs, Department of Political Science and International Studies and former Visiting Lecturer of the Josai Institute for Central European Studies Josai International University, Tokyo, Japan, Jagiellonian University, Poland, Warsaw University, Poland, and Visiting Lecturer at Ivan Franko National University in L'viv. She holds dual MA from the Central European University, Budapest and the New York State University, Albany, the MSc degree from Budapest Business School and a PhD on Political Science from the University of Pecs. She specializes on International Political Economy and Comparative Political Studies of the Central and Eastern European region. She is author of several articles and book chapters related to Central and Eastern European and post-Soviet region. 